\title{
Crystal Structures of Three Crystalline Forms of Poly(vinylidene fluoride)
}

\author{
Ryozo Hasegawa, * Yasuhiro Takahashi, Yozo Chatani, \\ and Hiroyuki TADOKORO \\ Department of Polymer Science, Faculty of Science, Osaka University, \\ Toyonaka, Osaka 560, Japan.
}

(Received January 6, 1972)

\begin{abstract}
The crystal structures of three forms of poly(vinylidene fluoride) were studied by X-ray diffraction method. Although the structure of form I has been determined to be a fully extended planar zigzag by Lando, et al. [orthorhombic; $a=$ $8.58 \AA, b=4.91 \AA$, and $c$ (fiber axis) $=2.56 \AA$; space group $\left.\mathrm{Cm} 2 \mathrm{~m}\left(\mathrm{C}_{2 \mathrm{v}}^{14}\right)\right]$, an alternatelydeflected molecular structure was postulated in order to release the steric hindrance between the fluorine atoms along the chain. A satistically disordered packing of such deflected chains satisfies the observed fiber period and improves appreciably the structure factor agreement. Form II is monoclinic [pseudo-orthorhombic; $a=4.96 \AA, b=9.64 \AA$, $c$ (fiber axis $)=4.62 \AA$, and $\beta=90^{\circ}$; space group $\left.P 2_{1} / c\left(C_{2}^{5}\right)\right]$, and its cell contains two molecular chains. The molecular conformation is essentially the $T G T \vec{G}$ type (internal rotation angles, $179^{\circ}$ and $45^{\circ}$ ), and the glide plane of the molecular chain coincides with the $c$ glide plane of the lattice. It is suggested that form III is monoclinic [ $a=$ $8.66 \AA, b=4.93 \AA, c$ (fiber axis) $=2.58 \AA$, and $\beta=97^{\circ}$; space group $\left.C 121\left(C_{2}^{3}\right)\right]$, and the structural features similar to that of form I.

KEY WORDS Poly(vinylidene fluoride) / Crystal Form / X-ray

Diffraction / Structure Analysis / Molecular Conformation /

Molecular Packing / Intramolecular Steric Hindrance / Statistically

Disordered Crystal Structure / Crystalline Density /
\end{abstract}

The crystal structure of form I of poly(vinylidene fluoride) (PVDF) has been reported by several authors. ${ }^{1-7}$ Lando, et al. ${ }^{7}$ determined the crystal structure of form I by X-ray and wide-line NMR analyses. According to their result two planar zigzag chains pass through the orthorhombic unit cell with the space group $\mathrm{Cm} 2 \mathrm{~m}\left(\mathrm{C}_{2 \mathrm{v}}^{14}\right)$.

For form II, the molecular and crystal structures have been investigated by many authors. ${ }^{1-14}$ Gal'perin, et al., ${ }^{3}$ suggested the possibility of a $T G T \bar{G}$-type or a $(2 / 1)$ helix conformation similar to that of poly(vinylidene chloride) ${ }^{15,16}$ from the identity period of $4.57 \AA$. Here $T, G$, and $\bar{G}$ denote the trans and two types of gauche forms, respectively. Cortili and Zerbi, ${ }^{10,11}$ Enomoto, et al., ${ }^{12}$ and Boerio and Koenig ${ }^{13}$ supported the $T G T \bar{G}$ model by the vibrational

* Present address: Products Development Institute, Teijin Limited, Hinode-chō, Iwakuni, Yamaguchi, 740 Japan. spectroscopic studies. Recently, Doll and Lando ${ }^{9}$ proposed two possible structures with the space groups $\mathrm{P}{ }_{1}\left(\mathrm{C}_{2}^{2}\right)$ and $\mathrm{P} 1\left(\mathrm{C}_{1}^{1}\right)$ containing two chains of the conformation essentially of the $T G T \bar{G}$ type per unit cell.

Form III has been found in the specimen cast from dimethyl sulfoxide ${ }^{6,11}$ and also in the pressure-crystallized specimen. ${ }^{17,18}$ In a previous paper of the authors, ${ }^{18}$ a planar zigzag conformation was proposed for form III from the infrared spectroscopic data.

The present work was undertaken to study the molecular and crystal structures of the three forms of PVDF by an X-ray diffraction method. The molecular structure of form $I$ is discussed with respect to the steric hindrance between the fluorine atoms along the chain. The crystal structure of form II was found to be different from those proposed by Doll and Lando. ${ }^{9}$ For form III, the crystal structure that appear to be most reasonable based on present evidence is 
Crystal Structure of Poly(vinylidene fluoride)

proposed.

\section{EXPERIMENTAL}

\section{Samples}

The specimens of forms I, II, and III were prepared by the techniques described in a previous paper. ${ }^{19}$ A highly oriented crystalline specimen of form I was prepared by heat treatment of the oriented sample (drawn at $50^{\circ} \mathrm{C}$, $500 \%)$ under high pressure $\left(4000 \mathrm{~atm}, 285^{\circ} \mathrm{C}\right)$, giving the $\mathrm{X}$-ray pattern in Figure $1(\mathrm{a})$. An oriented specimen of form II was prepared by drawing the melt-crystallized film at $150^{\circ} \mathrm{C}$; draw ratio $400 \%$ (Figure 1(b)). The specimens of form III were obtained by (1) heat treatment of unoriented form II under a high pressure $\left(4000 \mathrm{~atm}, 285^{\circ} \mathrm{C}\right)^{18}$ and also (2) precipitation from dimethyl sulfoxide solution. ${ }^{6,11}$

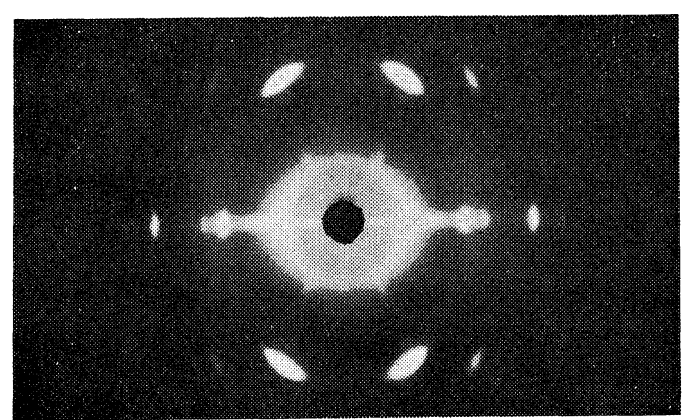

(a)

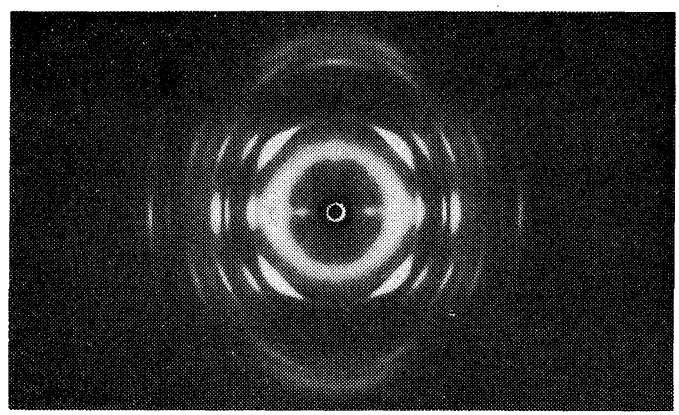

(b)

Figure 1. X-ray fiber patterns of poly(vinylidene fluoride): (a) highly oriented crystalline form I prepared by high-pressure treatment (4000 atm, $285^{\circ} \mathrm{C}$ ) of the ordinary drawn sample (draw ratio $500 \%$ ); (b) highly crystalline form II drawn at $150^{\circ} \mathrm{C}(400 \%)$, containing a small amount of form I.

\section{$X$-ray Measurement}

Throughout the present work, nickel-filtered $\mathrm{Cu}-\mathrm{K} \alpha$ radiation was used. Photographs were taken with a cylindrical camera, at radii of 45 $\mathrm{mm}$ or $35 \mathrm{~mm}$. The measurement of the Bragg angles was calibrated with reference to those of aluminum powder. In order to determine the fiber period precisely, a Weissenberg photograph was taken by setting the uniaxially oriented specimen with the fiber axis perpendicular to the camera axis, and by oscillating the specimen by $140^{\circ}$ around the camera axis. The reflection intensities obtained by the multiple film method were measured by visual comparison with a standard intensity scale. The correction for Lorentz-polarization factors was made.

\section{STRUCTURE ANALYSES AND RESULTS}

\section{Crystal Structure of Form I}

If one assumes a fully planar zigzag chain as reported by Lando, et al., ${ }^{7}$ the fiber period $2.56 \AA$ is too short when compared with twice the van der Waals radius of the fluorine atom, $2.70 \AA$ (Figure 2(a)). Those authors ${ }^{7}$ therefore suggested that the fluorine atoms must be crowded along the chain axis and the atomic thermal motions would be restricted along the $c$ axis, and reported that the $(00 l)$ reflections appear with a

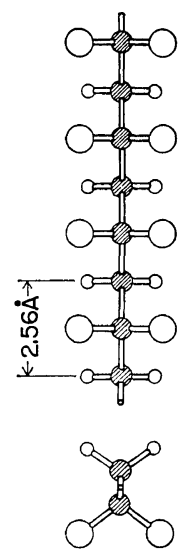

(a)
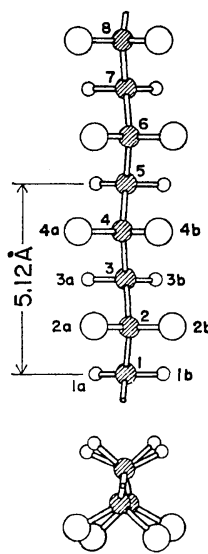

(b)
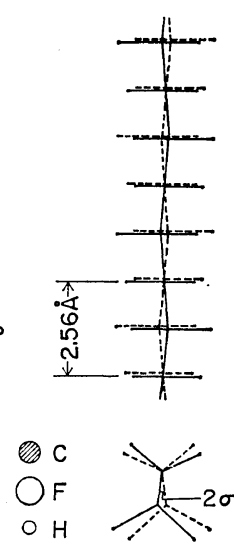

(c)
Figure 2. Molecular models of form I: (a) a planar zigzag chain; (b) an alternately deflected zigzag chain; (c) a deflected chain and its mirror image shown by solid and broken lines, respectively; $\sigma$, deflection angle. 
thermal parameter $\left(B=3.8 \AA^{2}\right)$ lower than that of the other types of reflection $\left(B=7.0 \AA^{2}\right)$. Gal'perin, et al. ${ }^{3}$ recognized this situation, and proposed tentatively that the $\mathrm{CF}_{2}$ groups are deflected statistically from the planar zigzag conformation.

In order to examine the molecular structure of form I in detail, the reflection data of the highly oriented crystalline specimen (Figure 1(a)) were analyzed. From this X-ray fiber pattern, intensity data of seventeen independent reflections on equatorial and first layer lines were available, whereas twelve reflection data were used by Lando, et al. ${ }^{7}$ All the reflections were indexed by an rectangular unit cell as already reported; $7^{7} \quad a=8.58 \AA, \quad b=4.91 \AA$, and $c$ (fiber axis) $=2.56 \AA$. This values are slightly different from those reported by them. The space group of $\mathrm{Cm} 2 \mathrm{~m}\left(\mathrm{C}_{2 \mathrm{v}}^{14}\right)$ was confimed from the systematic absence $h+k \neq 2 n$ for $(h k l)$ reflections, as reported by previous authors.,

As an attempt to release the steric hindrance between the fluorine atoms, it was assumed that the chain has alternate deflections about the chain axis as shown in Figure 2(b). It was assumed for simplicity here that the chain axis passes through the carbon atoms $\left(\mathrm{C}_{1}\right.$ and $\mathrm{C}_{2}$ etc.) of $\mathrm{CF}_{2}$ groups, and that the deflected $\mathrm{CF}_{2}$ groups are located on the planes perpendicular to the chain axis. In this molecular model, a deflection angle $\sigma$ was defined as the deviation of the main chain from the planar zigzag conformation (Figure 2). By introducing the deflection angle, the F...F distance should become greater than $2.56 \AA$. This deflected model should, however, have an identity period $5.12 \AA$, twice that of the planar zigzag chain (see Figure 2(b)). No layer line corresponding to the period $5.12 \AA$ was observed in the X-ray fiber pattern (Figure 1(a)). If two deflected chains, which are mirror images of each other, are located

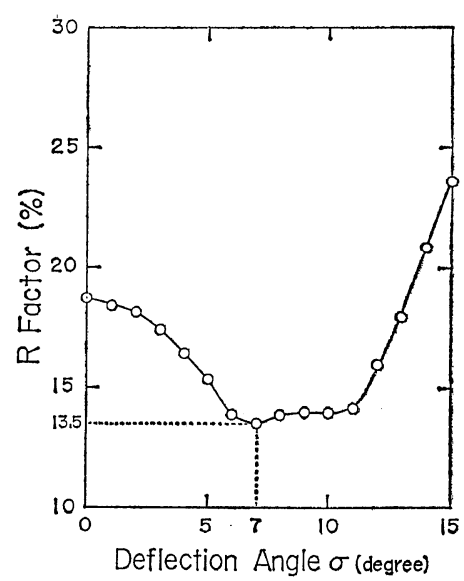

Figure 3. Variation of the discrepancy factor $R$ with the deflection angle $\sigma$ in the structure factor calculation of form I.
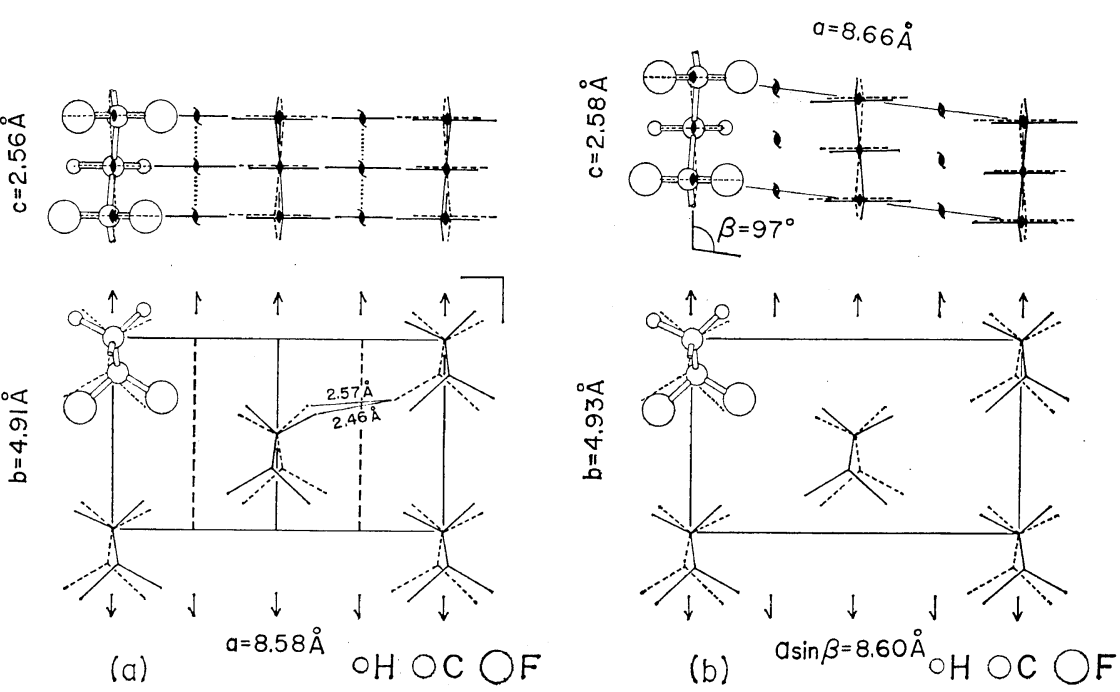

Figure 4. Statistically disordered crystal structure of (a) form I and (b) form III of poly(vinylidene fluoride). 
with equal probability as shown in Figure 2(c) by solid and broken lines, this structure can satisfy the observed fiber period of $2.56 \AA$ and also the space group symmetry of $\mathrm{Cm} 2 \mathrm{~m}\left(\mathrm{C}_{2 \mathrm{v}}^{14}\right)$.

In a starting model of the planar zigzag chain, the atomic coordinates were given by assuming the bond distance $\mathrm{C}-\mathrm{C}=1.54 \AA \mathrm{A}, \mathrm{C}-\mathrm{F}=1.34 \AA$ $\mathrm{C}-\mathrm{H}=1.09 \AA$, and the bond angles $\mathrm{C}-\mathrm{C}-\mathrm{C}=$ $112.5^{\circ}, \mathrm{F}-\mathrm{C}-\mathrm{F}=108^{\circ}$, and $\mathrm{H}-\mathrm{C}-\mathrm{H}=112^{\circ}$. The structure factors were calculated for various deflection angles from $0^{\circ}$ to $15^{\circ}$. In this study the hydrogen atoms were taken into account for the structure factor calculations of all three modifications. Figure 3 illustrates a plot of the discrepancy factor $R[R=\Sigma|| F($ obsd $) \mid-$ $\mid F($ calcd) ||$/ \Sigma \mid F$ (obsd) $\mid]$ against the deflection angle $\sigma$. The curve passes through a minimum $(R=$ $13.5 \%)$ at $\sigma=7^{\circ}$. Here an isotropic thermal parameter $B=5.0 \AA^{2}$ was assumed for all atoms. Thus the result supported the aforementioned statistically-disordered crystal structure with the alternately-deflected zigzag chains $\left(\sigma=7^{\circ}\right)$, as shown in Figure 4(a).

In Table I are listed the atomic coordinates of (a) the planar zigzag structure $\left(\sigma=0^{\circ}\right)$ and (b) the statistically-disordered crystal structure with the deflected zigzag chains $\left(\sigma=7^{\circ}\right)$. The observed and calculated intensities are compared

Table I. Atomic coordinates of form I of poly(vinylidene fluoride)

(a) Planar zigzag structure $\left(\sigma=0^{\circ}\right)$

\begin{tabular}{cccl}
\hline atom $^{\mathrm{a}}$ & $x / a$ & $y / b$ & \multicolumn{1}{c}{$z / c$} \\
\hline $\mathrm{C}_{1}$ & 0.0 & 0.0 & 0.0 \\
$\mathrm{C}_{2}$ & 0.0 & 0.174 & 0.500 \\
$\mathrm{~F}_{2 \mathrm{a}}$ & 0.126 & 0.355 & 0.500 \\
$\mathrm{~F}_{2 \mathrm{~b}}$ & -0.126 & 0.355 & 0.500 \\
$\mathrm{H}_{1 \mathrm{a}}$ & 0.105 & -0.124 & 0.0 \\
$\mathrm{H}_{1 \mathrm{~b}}$ & -0.105 & -0.124 & 0.0 \\
\hline
\end{tabular}

(b) Statistically disordered crystal structure $\left(\sigma=7^{\circ}\right)$

\begin{tabular}{cccl}
\hline atom $^{\mathrm{a}}$ & $x / a$ & $y / b$ & \multicolumn{1}{c}{$z / c$} \\
\hline $\mathrm{C}_{1}$ & 0.0 & 0.0 & 0.0 \\
$\mathrm{C}_{2}$ & 0.012 & 0.173 & 0.500 \\
$\mathrm{~F}_{2 \mathrm{a}}$ & 0.148 & 0.305 & 0.500 \\
$\mathrm{~F}_{2 \mathrm{~b}}$ & -0.102 & 0.359 & 0.500 \\
$\mathrm{H}_{1 \mathrm{a}}$ & 0.094 & -0.149 & 0.0 \\
$\mathrm{H}_{1 \mathrm{~b}}$ & -0.112 & -0.111 & 0.0 \\
\hline
\end{tabular}

a Numbering of atoms is shown in Figure 2. for both the cases in Table II. The alternately deflected chains release the F...F distance from $2.56 \AA\left(\sigma=0^{\circ}\right)$ to $2.60 \AA\left(\sigma=7^{\circ}\right)$. The resultant

Table II. Comparison between observed and calculated intensites of form $I$ of poly(vinylidene fluoride): (a) planar zigzag structure $\left(\sigma=0^{\circ}\right)$ and (b) statistically disordered structure with alternately deflected zigzag chains $\left(\sigma=7^{\circ}\right)$

\begin{tabular}{|c|c|c|c|c|}
\hline \multirow{2}{*}{$h k l$} & \multicolumn{2}{|c|}{ (a) } & \multicolumn{2}{|c|}{ (b) } \\
\hline & $\sqrt{\bar{I}_{\mathrm{o}}} \mathrm{a}$ & ${\sqrt{I_{\mathrm{c}}}}^{\mathrm{b}}$ & $\sqrt{I_{\mathrm{o}}}$ & $\sqrt{\sqrt{I_{\mathrm{c}}}}$ \\
\hline $\left.\begin{array}{l}200 \\
110\end{array}\right\}$ & 77.7 & 56.6 & 65.4 & 55.7 \\
\hline $\left.\begin{array}{l}310 \\
020\end{array}\right\}$ & 33.8 & 43.3 & 28.5 & 37.2 \\
\hline $\left.\begin{array}{l}400 \\
220\end{array}\right\}$ & 16.4 & 16.5 & 13.8 & 12.8 \\
\hline $\left.\begin{array}{l}510 \\
420 \\
130\end{array}\right\}$ & 32.0 & 39.3 & 27.0 & 31.8 \\
\hline $\left.\begin{array}{l}600 \\
330\end{array}\right\}$ & 13.3 & 14.7 & 11.2 & 11.4 \\
\hline $\left.\begin{array}{l}620 \\
040\end{array}\right\}$ & 9.0 & 7.1 & 7.5 & 6.6 \\
\hline $\left.\begin{array}{l}710 \\
530 \\
240\end{array}\right\}$ & 10.3 & 13.3 & 8.7 & 9.8 \\
\hline $\left.\begin{array}{l}800 \\
440\end{array}\right\}$ & 10.7 & 14.6 & 9.0 & 8.6 \\
\hline $\left.\begin{array}{l}820 \\
730 \\
150\end{array}\right\}$ & 9.3 & 8.1 & 7.8 & 5.1 \\
\hline $\left.\begin{array}{l}910 \\
640 \\
350\end{array}\right\}$ & 7.5 & 6.5 & 6.3 & 6.2 \\
\hline $\left.\begin{array}{l}201 \\
111\end{array}\right\}$ & 42.8 & 39.2 & 37.3 & 38.4 \\
\hline $\left.\begin{array}{l}311 \\
021\end{array}\right\}$ & 20.9 & 25.6 & 18.3 & 23.3 \\
\hline $\left.\begin{array}{l}401 \\
221\end{array}\right\}$ & 18.5 & 20.2 & 16.1 & 15.6 \\
\hline $\left.\begin{array}{l}511 \\
421 \\
131\end{array}\right\}$ & 17.2 & 19.7 & 15.0 & 14.2 \\
\hline $\left.\begin{array}{l}601 \\
331\end{array}\right\}$ & 17.5 & 16.6 & 15.3 & 13.8 \\
\hline $\left.\begin{array}{l}621 \\
041\end{array}\right\}$ & 12.4 & 8.5 & 10.8 & 9.1 \\
\hline $\left.\begin{array}{l}711 \\
531 \\
241\end{array}\right\}$ & 15.1 & 14.6 & 13.2 & 11.5 \\
\hline $\begin{array}{l}\text { The o } \\
\text { on th } \\
\text { setting } \\
\text { factor } \\
\sqrt{I_{0}} \text { ' } \\
\text { fiber }\end{array}$ & $\begin{array}{l}\text { ed st } \\
\text { ne sc } \\
\sqrt{I_{0}} \\
m \text { is } \\
\text { he re }\end{array}$ & $\begin{array}{l}\text { re fact } \\
\text { s the } \\
m F_{\mathrm{c}}^{2} \text {, } \\
\text { nultipl } \\
\text { ons wh }\end{array}$ & $\begin{array}{l}\sqrt{I_{\mathrm{o}}} \\
(= \\
\text { re } k \\
\text { over } \\
\text { o }\end{array}$ & $\begin{array}{l}\text { re put } \\
c^{2} \text { )'s by } \\
\text { e scale } \\
\text { X-ray }\end{array}$ \\
\hline
\end{tabular}


molecular dimensions are as follows: the bond angle $\mathrm{C}_{1}-\mathrm{C}_{2}-\mathrm{C}_{3}=112.7^{\circ}$ and the internal rotation angle $\mathrm{C}_{1}-\mathrm{C}_{2}-\mathrm{C}_{3}-\mathrm{C}_{4}=171.6^{\circ}$.

The inter-chain fluorine...hydrogen distances are $2.57 \AA$ and $2.46 \AA$ as shown in Figure $4(\mathrm{a})$. These distances correspond to the closest approach between fluorine and hydrogen atoms. In fact, the calculated crystalline density of form $\mathrm{I}$ is the highest, $1.97_{3} \mathrm{~g} / \mathrm{cc}$, among the three modifications.

\section{Crystal Structure of Form II}

In the X-ray fiber photograph of form II shown in Figure 1(b), fifty-two independent reflections were available, and indexed by a rectangular unit cell; $a=4.96 \AA, b=9.64 \AA$, and $c$ (fiber axis $)=4.62 \AA$. Assuming four monomeric units (two polymer chains) in the unit cell, the calculated density is $1.92_{5} \mathrm{~g} / \mathrm{cc}$. This value is acceptable in comparison with the observed density, $1.78_{8} \mathrm{~g} / \mathrm{cc}$ at $30^{\circ} \mathrm{C}$ (see Table I ref 19 ).

At first an orthorhombic symmetry was postulated. By considering the fiber period and the systematic absences of the reflections $l \neq 2 n$ for $(00 l)$ and $k \neq 2 n$ for $(0 k 0)$, a corresponding $(2 / 1)$ helical model (Figure 5(b)) and a possible space group $P 22_{1} 2_{1}\left(D_{2}^{3}\right)$ were adopted. The structure of form II, however, could not be determined in terms of any of the orthorhombic systems with the $(2 / 1)$ helical model.

Finally a monoclinic cell with the rectangular lattice $\left(\beta=90^{\circ}\right)$ was taken as the case of rubber hydrochloride reported by Bunn and Garner. ${ }^{20}$ In the X-ray fiber photograph taken with a distance of $30 \mathrm{~cm}$ between the specimen and the film, no resolution between the $(h k l)$ and $(\bar{h} k l)$ reflections was observed on the first and second layer lines. Since all the $(h 0 l)$ reflections with $h \neq 0$ and $l \neq 2 n$ overlap on the other reflections, it was difficult to decide whether (a) the absences $l \neq 2 n$ for all $(00 l)$ and $k \neq 2 n$ for $(0 k 0)$ (proposed by Doll and Lando $^{9}$ ) or (b) $l \neq 2 n$ for $(h 0 l)$ and $k \neq 2 n$ for $(0 k 0)$ are the case. However, the latter one (b) was assumed here. These systematic absences indicated a possible space group of $\mathrm{P} 2_{1} / \mathrm{c}\left(\mathrm{C}_{2 \mathrm{~h}}^{5}\right)$.

Of the two possible molecular models shown in Figure 5, the $T G T \bar{G}$ model with a glide plane coinciding with the $c$ glide plane of the lattice was taken unequivocally from the require-
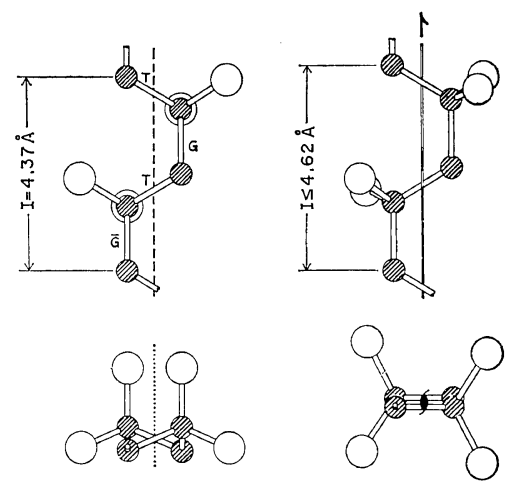

(TGTG)Model

\section{(2/1) Model}

$\mathrm{C} \bigcirc \mathrm{F}$

Figure 5. Possible molecular models for form II: (a) $T G T \bar{G}$ type and (b) (2/1) helix.
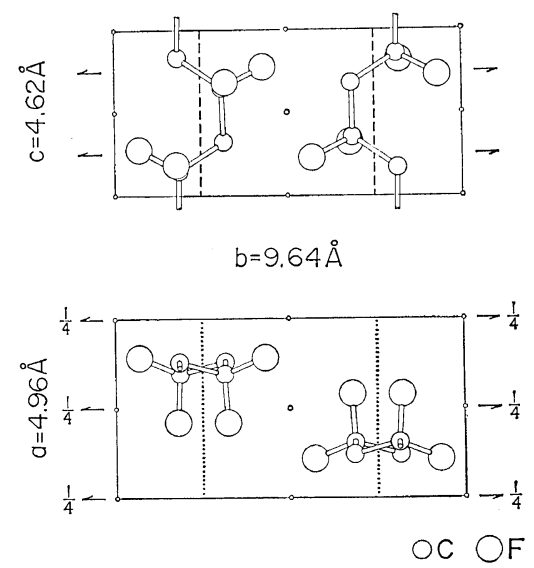

Figure 6. Crystal structure of form II of poly (vinylidene fluoride).

ment of the space group $\mathrm{P} 2_{1} / \mathrm{c}\left(\mathrm{C}_{2 \mathrm{~h}}^{5}\right)$. The observed fiber period was $4.62 \AA$ which is slightly larger than the value $4.37 \AA$ calculated from the $\mathrm{C}-\mathrm{C}$ bond length $=1.54 \AA$ and the $\mathrm{C}-\mathrm{C}-\mathrm{C}$ bond angle $=109.5^{\circ}$. Placing slightly extended $T G T \bar{G}$ chains on the glide planes at $(1 / 4) b$ and $(3 / 4) b$ in the unit cell (see Figure 6), the atomic parameters were refined by trial and error procedures and a least-squares method, giving a discrepancy factor $R=17 \%$ for all the observed fifty-two reflections. The final atomic coordinates and the individual isotropic thermal parameters are listed in Table III. The observed and 
Crystal Structure of Poly(vinylidene Fluoride)

Table III. Atomic coordinates and isotropic thermal parameters of form II of poly(vinylidene fluoride)

\begin{tabular}{ccccc}
\hline Atom $^{\mathrm{a}}$ & $x / a$ & $y / b$ & $z / c$ & $B, \AA^{2}$ \\
\hline $\mathrm{C}_{1}$ & 0.238 & 0.183 & 0.825 & 4.0 \\
$\mathrm{C}_{2}$ & 0.308 & 0.186 & 0.150 & 5.0 \\
$\mathrm{~F}_{1}$ & 0.218 & 0.070 & 0.276 & 3.5 \\
$\mathrm{~F}_{2}$ & 0.576 & 0.178 & 0.185 & 7.0 \\
$\mathrm{H}_{1}$ & 0.366 & 0.096 & 0.760 & 3.5 \\
$\mathrm{H}_{2}$ & 0.021 & 0.166 & 0.806 & 7.0 \\
\hline
\end{tabular}

a Numbering of atoms is shown in Figure 7.
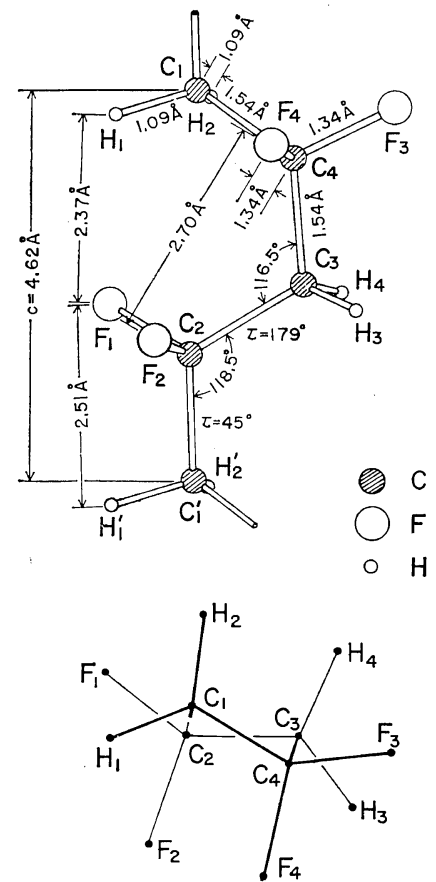

Figure 7. Molecular structure of form II.

calculated intensities are compared in Table IV.

The crystal and molecular structures of form II are shown in Figures 6 and 7, respectively, and the molecular dimensions are given in Table $\mathrm{V}$. The internal rotation angles of the main chain are $179^{\circ}$ and $45^{\circ}$, the latter deviating considerably from the exact gauche form $\left(60^{\circ}\right)$. The distance $F_{2} \cdots F_{4}$ is $2.70 \AA$, just coinciding with twice the van der Waals radius of the fluorine atom, and is larger than the value $(2.60 \AA)$ of the alternately deflected zigzag chain in form $\mathrm{I}$.
Table IV. Comparison between observed and calculated intensities of form II of poly(vinylidene fluoride)

\begin{tabular}{|c|c|c|c|c|c|}
\hline$h k l^{\mathrm{a}}$ & $\sqrt{\bar{I}_{\mathrm{o}}}{ }^{\mathrm{b}}$ & $\sqrt{\bar{I}_{\mathrm{c}}} \mathrm{c}$ & $h k l^{\mathrm{a}}$ & $\sqrt{{\overline{I_{\mathrm{o}}}}^{\mathrm{b}}}$ & $\sqrt{\bar{I}_{\mathrm{c}}} \mathrm{c}$ \\
\hline 100 & 40.5 & 36.2 & 241 & 34.9 & 39.3 \\
\hline 020 & 44.4 & 35.8 & 311 & 23.7 & 24.4 \\
\hline 110 & 69.2 & 70.3 & 061 & 19.7 & 13.3 \\
\hline 120 & 32.7 & 39.3 & $\left.\begin{array}{l}321 \\
161\end{array}\right\}$ & 9.7 & 12.3 \\
\hline 130 & 33.3 & 37.3 & $\begin{array}{l}161\} \\
251\end{array}$ & - & 8.1 \\
\hline 200 & 37.7 & 41.2 & 331 & 14.5 & 3.8 \\
\hline $\left.\begin{array}{l}040 \\
210\end{array}\right\}$ & 32.8 & 29.9 & $071\}$ & 21.1 & 21.0 \\
\hline $\left.\begin{array}{l}220 \\
140\end{array}\right\}$ & 6.3 & 14.7 & $\begin{array}{l}341 \text { S } \\
261 \text { ? }\end{array}$ & & \\
\hline 230 & 13.1 & 9.9 & $171\}$ & 20.9 & 18.2 \\
\hline 150 & 26.1 & 19.4 & 351 & 15.6 & 5.5 \\
\hline 240 & 5.1 & 3.8 & $411\}$ & & \\
\hline $\left.\begin{array}{l}300 \\
310\end{array}\right\}$ & 37.9 & 45.1 & $\left.\begin{array}{l}081 \\
271\end{array}\right\}$ & 11.0 & 6.5 \\
\hline 060 & - & 9.3 & 421 & - & 5.7 \\
\hline 320 & 13.0 & 13.2 & $181\}$ & 3 & \\
\hline $\left.\begin{array}{l}160 \\
250\end{array}\right\}$ & 19.5 & 19.4 & $\left.\begin{array}{l}431 \\
361\end{array}\right)$ & 22.3 & 15.0 \\
\hline 330 & - & 10.1 & 441 & 16.1 & 14.8 \\
\hline $\begin{array}{l}340 \\
260\end{array}$ & 6.1 & 11.2 & $\left.\begin{array}{l}102 \\
022\end{array}\right\}$ & 18.5 & 18.8 \\
\hline 170 & 15.8 & 11.5 & 112 & 23.1 & 35.0 \\
\hline 350 & - & 0.2 & 122 & 20.1 & 14.6 \\
\hline $\begin{array}{l}400 \\
410\end{array}$ & 15.2 & 13.8 & $\begin{array}{l}032 \\
132\end{array}$ & $\overline{278}$ & 11.6 \\
\hline $\begin{array}{l}410 \\
420\end{array}$ & & & $\begin{array}{l}132 \\
202\end{array}$ & 27.8 & 27.4 \\
\hline $\begin{array}{l}270 \\
080\end{array}$ & 27.3 & 26.5 & $\left.\begin{array}{l}042 \\
212\end{array}\right\}$ & 26.3 & 28.6 \\
\hline 180 & - & 4.9 & $\left.\begin{array}{l}222 \\
143\end{array}\right\}$ & 18.7 & 14.6 \\
\hline 430 & - & 12.9 & $\begin{array}{l}142) \\
232\end{array}$ & 7.4 & 8.3 \\
\hline 360 & - & 8.6 & 052 & - & 9.1 \\
\hline 440 & $\overline{19.9}$ & $\begin{array}{r}1.7 \\
17.1\end{array}$ & 152 & 24.9 & 16.8 \\
\hline $\begin{array}{l}280 \\
370\end{array}$ & $\begin{array}{l}19.9 \\
15.7\end{array}$ & $\begin{array}{l}17.1 \\
13.5\end{array}$ & 242 & - & 3.0 \\
\hline $\left.\begin{array}{l}190 \\
450\end{array}\right\}$ & 15.6 & 18.2 & $\left.\begin{array}{l}302 \\
312\end{array}\right\}$ & 21.7 & 22.3 \\
\hline $\begin{array}{l}430) \\
011\end{array}$ & - & 12.3 & 062 & - & 2.0 \\
\hline 021 & 51.4 & 48.9 & $\begin{array}{l}322 \\
162\end{array}$ & 115 & 122 \\
\hline 111 & 28.6 & 35.1 & $\left.\begin{array}{l}162 \\
252\end{array}\right\}$ & 11.5 & 12.2 \\
\hline 121 & 28.9 & 29.3 & 332 & - & 9.3 \\
\hline 031 & 12.5 & 31.6 & 342 & - & 1.3 \\
\hline 131 & 36.1 & 34.2 & 262 & - & 9.8 \\
\hline $\left.\begin{array}{l}211 \\
041\end{array}\right\}$ & 24.0 & 23.1 & 072 & - & 3.7 \\
\hline 221) & & & 352 & - & $\begin{array}{r}3.1 \\
8.3\end{array}$ \\
\hline 141$\}$ & 35.3 & 43.7 & $\begin{array}{l}172 \\
402\end{array}$ & - & 8.3 \\
\hline $\left.\begin{array}{l}231 \\
051\end{array}\right\}$ & 14.5 & 20.0 & $\begin{array}{l}412 \\
083\end{array}$ & 18.1 & 19.4 \\
\hline 151 & 24.8 & 25.9 & 272 & & \\
\hline
\end{tabular}

a An index $(h k l)$ denotes the both $(h k l)$ and $(\bar{h} k l)$ reflections on the first and second layers.

b The observed structure factors $\sqrt{I_{\mathrm{o}}}$ 's were put on the same scale as the $\sqrt{I_{\mathrm{c}}}\left(=\sqrt{m F_{\mathrm{c}}^{2}}\right)$ 's by setting $\Sigma k \sqrt{I_{0}}=\Sigma \sqrt{m F_{\mathrm{c}}^{2}}$, where $k$ is the scale factor and $m$ is the multiplicity.

c $\sqrt{I_{\mathrm{c}}}$ 's of the reflections which overlap on X-ray fiber photographs are $\sqrt{\Sigma m F_{\mathrm{c}}^{2}}$. 

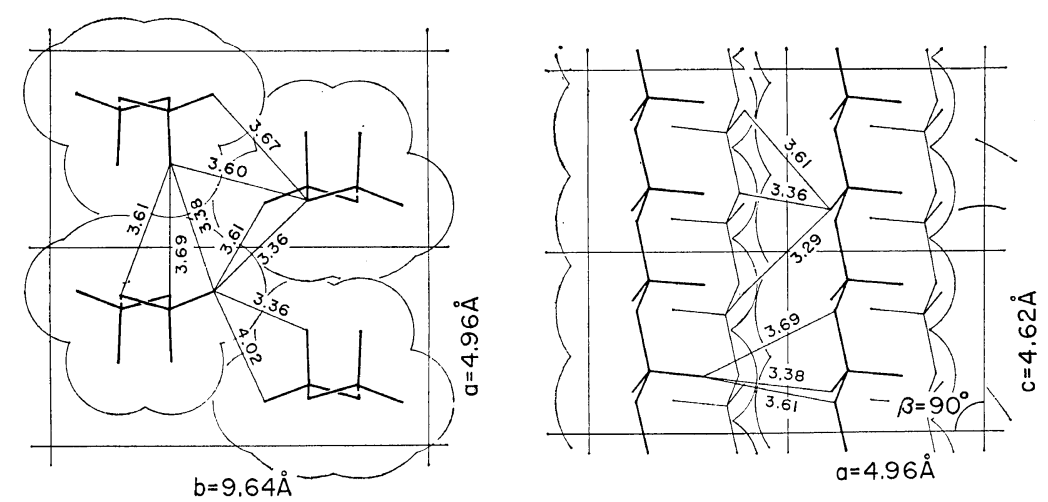

Figure 8. Molecular chain arrangement and interchain atomic distances (in $\AA$ ) of form II. (a) The projection along the $c$ axis (b); the projection along the $b$ axis.

Table V. Molecular dimensions of form II of poly(vinylidene fluoride)

\begin{tabular}{lll}
\hline Bond length & $\mathrm{C}_{1}-\mathrm{C}_{2}=\mathrm{C}_{2}-\mathrm{C}_{3}{ }^{\mathrm{a}}$ & $1.54 \AA$ \\
& $\mathrm{C}_{2}-\mathrm{F}_{1}=\mathrm{C}_{2}-\mathrm{F}_{2}$ & $1.34 \AA$ \\
Bond angle & $\mathrm{C}_{1}-\mathrm{H}_{1}=\mathrm{C}_{1}-\mathrm{H}_{2}$ & $1.09 \AA$ \\
& $\mathrm{C}_{1}-\mathrm{C}_{2}-\mathrm{C}_{3}$ & $118.5^{\circ}$ \\
& $\mathrm{C}_{2}-\mathrm{C}_{3}-\mathrm{C}_{4}$ & $116.5^{\circ}$ \\
& $\mathrm{C}_{1}-\mathrm{C}_{2}-\mathrm{F}_{1}$ & $109^{\circ}$ \\
& $\mathrm{C}_{1}-\mathrm{C}_{2}-\mathrm{F}_{2}$ & $110^{\circ}$ \\
& $\mathrm{C}_{3}-\mathrm{C}_{2}-\mathrm{F}_{1}$ & $112^{\circ}$ \\
& $\mathrm{C}_{3}-\mathrm{C}_{2}-\mathrm{F}_{2}$ & $102^{\circ}$ \\
& $\mathrm{F}_{1}-\mathrm{C}_{2}-\mathrm{F}_{2}$ & $103^{\circ}$ \\
Internal rotation angle & $\mathrm{C}_{1}-\mathrm{C}_{2}-\mathrm{C}_{3}-\mathrm{C}_{4}$ & $179^{\circ}$ \\
& $\mathrm{C}_{4}-\mathrm{C}_{1}-\mathrm{C}_{2}-\mathrm{C}_{3}$ & $45^{\circ}$ \\
Nonbonded interatomic & & \\
distance & $\mathrm{F}_{2} \cdots \mathrm{F}_{4}$ & $2.70 \AA$ \\
& $\mathrm{F}_{1} \cdots \mathrm{H}_{1}$ & $2.37 \AA$ \\
& $\mathrm{F}_{1} \cdots \mathrm{H}_{1}{ }^{\prime}$ & $2.51 \AA$ \\
& $\mathrm{H}_{2} \cdots \mathrm{H}_{4}$ & $2.82 \AA$ \\
\hline
\end{tabular}

a Numbering of atoms is shown in Figure 7.

In Figure 8 the molecular chain arrangement in the crystal lattice and close interchain-atomic distances $(\mathrm{C} . \mathrm{F}$ and $\mathrm{F} . \mathrm{F})$ are indicated. All the values of these interatomic distances are acceptable, since the van der Waals radii of the fluorine atom and methylene group are $1.35 \AA$ and $2.00 \AA$, respectively. These radii are illustrated in Figure 8 with circles for indidividual atoms.

\section{Crystal Structure of Form III}

Form III was prepared (1) by heat treatment of unoriented form II under a high pressure and also (2) by casting from dimethyl sulfoxide, as mentioned in ref 19 . The X-ray powder patterns (Figure 2 of ref 19) and infrared spectra (Figure 3 of ref 19) are shown for both the specimens. The specimen obtained by the method (2) may be the pure form III, since the specimen prepared under a high pressure gave the X-ray patterns and infrared spectra having the superposition feature of form $I$ and of the form III cast from dimethyl sulfoxide.

The X-ray powder patterns of form III (Figures 2(c) and (d) of ref 19) are similar to that of form I (Figure 2(b) of ref 19), indicating that the crsytal structure of form III is similar to that of form I. Sixteen and fourteen independent reflections, respectively, were available in the X-ray patterns of both the specimens prepared by the methods (1) and (2). All the reflections of both the specimens were indexed by a monoclinic unit cell which is slightly deformed from the orthorhombic cell of form I (see Figure 4(a)). The cell dimensions are as follows: $a=8.66 \AA, \quad b=4.93 \AA, c$ (fiber axis) $=$ $2.58 \AA$, and $\beta=97^{\circ}$. In Table VI, the spacings of the observed reflections of both the specimens are compared with the calculated spacings and also with those of form I. Assuming two monomeric units in the unit cell, the calculated density is $1.94_{4} \mathrm{~g} / \mathrm{cc}$. This value is acceptable in comparison with the observed values of the samples prepared by the methods (1) $1.80_{2} \mathrm{~g} / \mathrm{cc}$ and (2) $180_{4} \mathrm{~g} / \mathrm{cc}$ at $30^{\circ} \mathrm{C}$ (see Table I of ref 19). Owing to the systematic absence $h+k \neq 2 n$ for ( $h k l)$ reflections, the most acceptable space group is $\mathrm{C} 121\left(\mathrm{C}_{2}^{3}\right)$, as compared with $\mathrm{Cm} 2 \mathrm{~m}\left(\mathrm{C}_{2 \mathrm{v}}^{14}\right)$ of 
Crystal Structure of Poly(vinylidene Fluoride)

Table VI. Observed and calculated spacings of forms I and III

\begin{tabular}{|c|c|c|c|c|c|c|}
\hline \multicolumn{3}{|c|}{ Form I } & \multicolumn{4}{|c|}{ Form III } \\
\hline Obsd,a A & Calcd, ${ }^{\mathrm{A}}$ & $h k l$ & $\operatorname{Obsd}(1),{ }^{\mathrm{c}} \AA$ & $\operatorname{Obsd}(2),{ }^{\mathrm{d}} \AA$ & Calcd, ^ & $h k l$ \\
\hline $4.27(\mathrm{vb})^{\mathrm{f}}$ & $\left\{\begin{array}{l}4.29 \\
4.26\end{array}\right.$ & $\begin{array}{l}200 \\
110\end{array}$ & $4.29(\mathrm{vb})$ & $4.39(v b)$ & $\left\{\begin{array}{l}4.30 \\
4.28\end{array}\right.$ & $\begin{array}{l}200 \\
110\end{array}$ \\
\hline 2.57 & 2.56 & 001 & 2.56 & $2.59(\mathrm{~h})$ & 2.56 & 001 \\
\hline 2.46 & $\left\{\begin{array}{l}2.47 \\
2.46\end{array}\right.$ & $\begin{array}{l}310 \\
020\end{array}$ & 2.46 & 2.46 & $\left\{\begin{array}{l}2.48 \\
2.46\end{array}\right.$ & $\begin{array}{l}310 \\
020\end{array}$ \\
\hline $2.18(\mathrm{~b})$ & $\left\{\begin{array}{l}2.20 \\
2.19 \\
2.14 \\
2.13\end{array}\right.$ & $\begin{array}{l}201 \\
111 \\
400 \\
220\end{array}$ & $\left.\begin{array}{l}2.33 \\
2.29\end{array}\right\}$ & $\begin{array}{l}2.30(\mathrm{vb}) \\
2.14\end{array}$ & $\begin{array}{l}\left\{\begin{array}{l}2.33 \\
2.26\end{array}\right. \\
\left\{\begin{array}{l}2.15 \\
2.14 \\
2.14 \\
2.09\end{array}\right.\end{array}$ & $\begin{array}{l}\overline{2} 01 \\
\overline{1} 11 \\
400 \\
111 \\
220 \\
201\end{array}$ \\
\hline 1.76 & $\left\{\begin{array}{l}1.78 \\
1.77\end{array}\right.$ & $\begin{array}{l}311 \\
021\end{array}$ & $1.75(b)$ & 1.76 & $\left\{\begin{array}{l}1.78 \\
1.76\end{array}\right.$ & $\frac{021}{401}$ \\
\hline $1.61(\mathrm{~b})$ & $\left\{\begin{array}{l}1.64 \\
1.64 \\
1.62 \\
1.62 \\
1.61\end{array}\right.$ & $\begin{array}{l}401 \\
221 \\
510 \\
420 \\
130\end{array}$ & $\begin{array}{l}1.67 \\
\left.\begin{array}{l}1.62 \\
1.60\end{array}\right\}\end{array}$ & $1.62(\mathrm{~b})$ & $\begin{array}{l}\left\{\begin{array}{l}1.69 \\
1.69\end{array}\right. \\
\left\{\begin{array}{l}1.62 \\
1.62 \\
1.61 \\
1.60\end{array}\right.\end{array}$ & $\begin{array}{l}311 \\
221 \\
510 \\
420 \\
130 \\
221\end{array}$ \\
\hline $1.40(\mathrm{~h})$ & $\left\{\begin{array}{l}1.43 \\
1.42\end{array}\right.$ & $\begin{array}{l}600 \\
330\end{array}$ & 1.40 & 1.41 & $\left\{\begin{array}{l}1.43 \\
1.43 \\
1.43\end{array}\right.$ & $\begin{array}{l}600 \\
421 \\
330\end{array}$ \\
\hline 1.36 & $\left\{\begin{array}{l}1.37 \\
1.37 \\
1.36\end{array}\right.$ & $\begin{array}{l}511 \\
421 \\
131\end{array}$ & 1.36 & 1.35 & $\left\{\begin{array}{l}1.38 \\
1.35\end{array}\right.$ & $\begin{array}{l}\overline{1} 31 \\
131\end{array}$ \\
\hline $\begin{array}{l}1.28 \\
1.23\end{array}$ & $\left\{\begin{array}{l}1.28 \\
1.25 \\
1.24 \\
1.24 \\
1.23 \\
1.23 \\
1.23\end{array}\right.$ & $\begin{array}{l}002 \\
601 \\
331 \\
620 \\
040 \\
202 \\
112\end{array}$ & $\begin{array}{l}1.28 \\
1.23(b)\end{array}$ & $\begin{array}{l}1.29 \\
1.23(\mathrm{~b})\end{array}$ & $\begin{array}{l}\left\{\begin{array}{l}1.28 \\
1.28 \\
1.27\end{array}\right. \\
\left\{\begin{array}{l}1.24 \\
1.23 \\
1.22 \\
1.21\end{array}\right.\end{array}$ & $\begin{array}{l}002 \\
331 \\
202 \\
620 \\
040 \\
331 \\
112\end{array}$ \\
\hline 1.14 & $\left\{\begin{array}{l}1.14 \\
1.14\end{array}\right.$ & $\begin{array}{l}312 \\
022\end{array}$ & $\begin{array}{l}1.20 \\
1.11\end{array}$ & 1.20 & $\begin{array}{l}\left\{\begin{array}{l}1.19 \\
1.19\end{array}\right. \\
\left\{\begin{array}{l}1.19 \\
1.19 \\
1.19\end{array}\right. \\
\left\{\begin{array}{l}1.11 \\
1.11\end{array}\right.\end{array}$ & $\begin{array}{l}710 \\
\overline{3} 12 \\
601 \\
202 \\
530 \\
\overline{5} 31 \\
041\end{array}$ \\
\hline 1.07 & $\left\{\begin{array}{l}1.08 \\
1.08 \\
1.07 \\
1.07 \\
1.07\end{array}\right.$ & $\begin{array}{l}711 \\
531 \\
241 \\
800 \\
440\end{array}$ & 1.08 & 1.08 & $\left\{\begin{array}{l}1.07 \\
1.07 \\
1.07 \\
1.07 \\
1.07\end{array}\right.$ & $\begin{array}{l}800 \\
621 \\
222 \\
440 \\
512\end{array}$ \\
\hline 1.00 & $\left\{\begin{array}{l}1.00 \\
1.00 \\
1.00\end{array}\right.$ & $\begin{array}{l}512 \\
422 \\
132\end{array}$ & & & & \\
\hline
\end{tabular}

a Observed spacings for the unoriented specimen of form I (see Figure 2(b) in ref 19).

b Spacings calculated from the unit cell of form I ( $a=8.58 \AA, b=4.91 \AA$, and $c=2.56 \AA$ ).

c (1) Observed spacings for the specimen prepared by heat treatment under a high pressure (see Figure 2(c) in ref 19).

d (2) Observed spacings for the specimen cast from dimethyl sulfoxide (see Figure 2(d) in ref 19).

- Spacings calculated from the unit cell of form III $\left(a=8.66 \AA, b=4.93 \AA, c=2.58 \AA\right.$, and $\left.\beta=97^{\circ}\right)$.

f vb, very broad; b, broad; $h$, halo. 
Table VII. Atomic coordinates of form III of poly(vinylidene fluoride)

(a) Planar zigzag structure $\left(\sigma=0^{\circ}\right)$

\begin{tabular}{cccc}
\hline atom $^{\mathrm{a}}$ & \multicolumn{1}{c}{$x / a$} & $y / b$ & \multicolumn{1}{c}{$z / c$} \\
\hline $\mathrm{C}_{1}$ & 0.0 & 0.0 & 0.0 \\
$\mathrm{C}_{2}$ & 0.0 & 0.171 & 0.500 \\
$\mathrm{~F}_{2 \mathrm{a}}$ & 0.126 & 0.330 & 0.552 \\
$\mathrm{~F}_{2 \mathrm{~b}}$ & -0.126 & 0.330 & 0.448 \\
$\mathrm{H}_{1 \mathrm{a}}$ & 0.105 & -0.124 & 0.043 \\
$\mathrm{H}_{1 \mathrm{~b}}$ & -0.105 & -0.124 & -0.043 \\
\hline
\end{tabular}

(b) Statistically disordered crystal structure $\left(\sigma=7^{\circ}\right)$

\begin{tabular}{cccc}
\hline atom $^{\mathrm{a}}$ & $x / a$ & $y / b$ & \multicolumn{1}{c}{$z / c$} \\
\hline $\mathrm{C}_{1}$ & 0.0 & 0.0 & 0.0 \\
$\mathrm{C}_{2}$ & 0.012 & 0.172 & 0.505 \\
$\mathrm{~F}_{2 \mathrm{a}}$ & 0.148 & 0.304 & 0.561 \\
$\mathrm{~F}_{2 \mathrm{~b}}$ & -0.102 & 0.358 & 0.458 \\
$\mathrm{H}_{1 \mathrm{a}}$ & 0.094 & -0.148 & 0.038 \\
$\mathrm{H}_{1 \mathrm{~b}}$ & -0.112 & -0.110 & -0.046 \\
\hline
\end{tabular}

a Numbering of atoms is shown in Figure 2. form I.

As shown in Figure 3 of ref 19, the similarity of the infrared spectra between form I (b) and III (c and d) suggested that the molecules have a nearly-planar zigzag conformation in form III. ${ }^{18}$ The structure factor calculations were made for the following two models. (I) There are two planar zigzag chains $\left(\sigma=0^{\circ}\right)$ in the unit cell in which a lateral view along the $c$ axis is similar to the Lando's model of form I. $^{7}$ (II) There are two deflected zigzag chains $\left(\sigma=7^{\circ}\right)$ in the unit cell in common with the statistically disordered crystal structure of form I (see Figure 4(a)). The atomic coordinates are listed for both the cases in Table VII. An isotropic thermal parameter $B=5.0 \AA^{2}$ was assumed for all atoms. For two kinds of speci-

Table VIII. Comparison between observed and calculated intensities of form III of poly(vinylidene fluoride)

\begin{tabular}{|c|c|c|c|c|c|c|c|c|c|}
\hline$h k l$ & $I_{\mathrm{o}}(1)^{\mathrm{a}}$ & $I_{\mathrm{o}}(2)^{\mathrm{b}}$ & $\boldsymbol{I}_{\mathrm{c}}(\mathbf{I})^{\mathrm{c}}$ & $I_{\mathrm{c}}(\mathrm{II})^{\mathrm{d}}$ & $h k l$ & $I_{0}(1)$ & $I_{\mathrm{o}}(2)$ & $I_{\mathrm{c}}(\mathbf{I})$ & $I_{\mathrm{c}}(\mathrm{II})$ \\
\hline $\begin{array}{l}200 \\
110\end{array}$ & vvs & vvs & 1000 & 1000 & $\begin{array}{l}511 \\
002)\end{array}$ & - & - & 0 & 0 \\
\hline 001 & $\mathrm{~s}$ & $\mathrm{~ms}$ & 80 & 83 & $\left.\frac{\overline{3}}{202}\right\}$ & $\mathrm{m}$ & $\mathrm{mw}$ & 11 & 10 \\
\hline $\left.\begin{array}{l}310 \\
020\end{array}\right\}$ & vs & vs & 190 & 160 & $\overline{1} 12$ & - & - & 4 & 4 \\
\hline $\left.\begin{array}{l}\overline{2} 01\} \\
\overline{1} 11\end{array}\right\}$ & vs & vs & 194 & 198 & $\left.\begin{array}{l}620 \\
040 \\
331\end{array}\right\}$ & w & $\mathrm{vw}$ & 8 & 6 \\
\hline $\left.\begin{array}{l}400 \\
111 \\
2201 \\
201\end{array}\right\}$ & vs & $\mathrm{s}$ & 75 & 69 & $\begin{array}{l}331 \\
112 \\
710 \\
\overline{3} 12\end{array}$ & 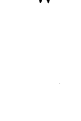 & . & & . \\
\hline$\overline{3} 11$ & - & - & 2 & 2 & $\left.\begin{array}{l}601 \\
202\end{array}\right\}$ & $\mathrm{vw}$ & vw & 4 & 2 \\
\hline$\frac{021}{401}$ & $\mathrm{~ms}$ & $\mathrm{~ms}$ & 54 & 49 & $530)$ & & & & \\
\hline $\left.\begin{array}{l}\frac{311}{2} 21 \\
\quad\end{array}\right\}$ & $\mathrm{vw}$ & vw & 22 & 16 & $\begin{array}{l}240 \\
\overline{4} 02\end{array}$ & - & - & $\begin{array}{l}0 \\
0\end{array}$ & $\begin{array}{l}0 \\
0\end{array}$ \\
\hline 510$\}$ & s) & & 47 & & $\overline{6} 21$ & - & - & 1 & 1 \\
\hline $\begin{array}{l}420) \\
130\}\end{array}$ & $m\}$ & $\mathrm{s}$ & 41 & 35 & 022 & - & - & 1 & 1 \\
\hline 221$\}$ & m) & & 15 & 19 & $\overline{7} 11$ & - & - & 1 & 0 \\
\hline 401 & - & - & 7 & 5 & $\begin{array}{l}\overline{2} 22 \\
\overline{5} 31\end{array}$ & - & - & 0 & 0 \\
\hline$\overline{5} 11$ & - & - & 5 & 3 & $\left.\begin{array}{l}531 \\
041\end{array}\right\}$ & $\mathrm{vw}$ & $\mathrm{vw}$ & 4 & 3 \\
\hline $\begin{array}{l}600 \\
421\end{array}$ & w & w & 15 & 11 & 312 & - & - & 1 & 1 \\
\hline 330) & & & 10 & 11 & $\overline{2} 41$ & - & - & 0 & 0 \\
\hline $\left.\begin{array}{l}\overline{1} 31 \\
131\end{array}\right\}$ & $\mathrm{vw}$ & vw & 1 & 1 & $\begin{array}{l}800 \\
621 \\
222\end{array}$ & vw & $\ldots$ & 6 & 4 \\
\hline $\begin{array}{l}\overline{6} 01 \\
421\end{array}$ & - & $=$ & $\begin{array}{l}0 \\
5\end{array}$ & $\begin{array}{l}0 \\
4\end{array}$ & $\begin{array}{l}440 \\
512\end{array}$ & & - & & \\
\hline
\end{tabular}

a $I_{\mathrm{o}}(1)$, the observed intensities of the pressure-crystallized specimen (intensities: $\mathrm{v}$, very; $\mathrm{s}$, strong; $\mathrm{m}$, medium; w, weak)

b $I_{0}(2)$, those of the specimen cast from dimethyl sulfoxide.

c $I_{\mathrm{c}}(\mathrm{I})$, the calculated intensities of the planar zigzag structure $\left(\sigma=0.0^{\circ}\right)$ in an arbitrary scale.

d $I_{\mathrm{c}}(\mathrm{II})$, those of the statistical structure with the deflected zigzag chain $\left(\sigma=7.0^{\circ}\right)$. 
mens indicated by (1) and (2), the observed and calculated intensities are compared in Table VIII. The calculated intensities were corrected for Lorentz-polarization factors on the DebyeScherrer rings.

In spite of the difflculty in determing the detailed structure, the crystal structure of form III was established as follows. As shown in Figure 4(b) the lateral chain arrangements are the same type as those of the statistically disordered structure of form I, and the origin of two crystal forms is attributed to the difference in the longitudinal chain packings.

\section{DISCUSSION}

Form I. Because of the intrachain steric hindrance in the planar zigzag chain, we have examined the possibility represented by alternately deflected zigzag chains. The statistically disordered crystal structure with such chains $(\sigma=$ $7^{\circ}$ ) improved the discrepancy factor $R$ from $18.5 \%$ to $13.5 \%$. The similar disorder was reported in the case of cis-1,4-polyisoprene by Nyburg $^{21}$ and also by Natta and Corradini. ${ }^{22}$ In ref 19 the alternately deflected zigzag chain $\left(\sigma=7^{\circ}\right)$ was proved to have a minimum intramolecular potential energy owing to release of the steric hindrance between fluorine atoms. Thus one has more evidence for the alternatelydeflected chains possibility, and may propose the statistically disordered crystal structure with such chains for form I. As another possible structure giving the same result in the structure factor calculation, it is considered that each chain has statistical deflection along the chain axis. $^{3}$ This statistically deflected chain, however, is less likely to exist than the alternately deflected chain owing to the intrachain steric hindrance.

Form II. The proposed structure of form II may be considered to be the most reasonable on present evidence. By adopting the space group of $P 2_{1} / \mathrm{c}\left(\mathrm{C}_{2 \mathrm{~h}}^{5}\right)$, the discrepancy factor $R$ was improved to $17 \%$ for the 52 observed independent reflections, whereas the structure of $\mathrm{P}_{1}\left(\mathrm{C}_{2}^{2}\right)$ proposed by Doll and $\mathrm{Lando}^{9}$ gave the $R$ factor of $22 \%$ for the 32 reflections. As shown in Figure 8, the structure obtained has well-packed molecular arrangements with respect to the contacts between the molecular chains. Despite the lower density of form II $\left(1.92_{5} \mathrm{~g} /\right.$ cc) compared with that of form $\mathrm{I}\left(1.97_{3} \mathrm{~g} / \mathrm{cc}\right)$, form II appears to be stable owing to the $T G T \bar{G}$ type molecular chains, as proved in ref 19.

Form III. The proposed crystal structure is regarded as a structure deformed from that of form I (see Figure 4). This situation is consistent with the experimental results described in ref 19; form III may be an intermediate one between forms I and II with respect to the pressure treatment, and is transformed into form I by heat treatment under a high pressure and by rolling.

Acknowledgement: The authors wish to thank Mr. T. Kusumoto of this laboratory for his collaboration to the analysis of form I.

\section{REFERENCES}

1. Yu. D. Kondrashov, Tr. GIPKh'a, No. 46, 166 (1960).

2. N. I. Makarevich and V.N. Nikitin, Vysokomolekul. Soedin., 7, 1673 (1965).

3. Ye. L. Gal'perin, Yu. V. Strogalin, and M.P. Mlenik, ibid., 7, 933 (1965).

4. Ye. L. Gal'perin and B. P. Kosmynin, ibid., 11, 1432 (1969).

5. G. Natta, G. Allegra, I. W. Bassi, D. Sianesi, G. Caporiccio, and E. Torti, J. Polym. Sci., Part A, 3, 4263 (1965).

6. K. Okuda, T. Yoshida, M. Sugita, and M. Asahina, ibid., Part B, 5, 465 (1967).

7. J. B. Lando, H. G. Olf, and A. Peterlin, ibid., Part A-1, 4, 941 (1966).

8. J. B. Lando and W. W. Doll, J. Macromol. Sci., B2, 205 (1968).

9. W. W. Doll and J. B. Lando, ibid., B4, 309 (1970).

10. G. Cortili and G. Zerbi, Spectrochim. Acta, 23A, 285 (1967).

11. G. Cortili and G. Zerbi, ibid., 23A, 2216 (1967).

12. S. Enomoto, Y. Kawai, and M. Sugita, $J$. Polym. Sci., Part A-2, 6, 861 (1968).

13. F. J. Boerio and J. L. Koenig, ibid., 7, 1489 (1969).

14. K. Sakaoku and A. Peterlin, J. Macromol. Sci., B1, 401 (1967).

15. T. Miyazawa and Y. Ideguchi, J. Polym. Sci., Part B, 3, 541 (1965).

16. R. C. Reinhardt, Industr. Engng. Chem., 35, 422 (1943). 
R. Hasegawa, Y. Takahashi, Y. Chatani, and H. Tadokoro

17. W. W. Doll and J. B. Lando, J. Macromol. Sci., B2, 219 (1968).

18. R. Hasegawa, Y. Tanabe, M. Kobayashi, H. Tadokoro, A. Sawaoka, and N. Kawai, J. Polym. Sci., Part A-2, 8, 1073 (1970).

19. R. Hasegawa, M. Kobayashi, and H. Tadokoro,
Polymer J., 3, 591 (1972).

20. C. W. Bunn and E. V. Garner, J. Chem. Soc., 1942, 654.

21. S. C. Nyburg, Acta Crystallogr., 7, 385 (1954).

22. G. Natta and P. Corradini, Angew. Chem., 68, 615 (1956). 